\section{Pericarp, seed coat anatomy and seed morphology of Calycanthaceae}

\author{
Niroj Paudel, Kweon Heo \\ Department of Applied Plant Sciences, \\ Kangwon National University, \\ Chuncheon, South Korea
}

\begin{abstract}
Pericarp, trichome, and seed coat anatomy display great features of taxonomic value in the Calycanthaceae. The present study about trichome and seed coat anatomy has based on external and internal observation. Detail anatomical study of seeds provides valuable information for further study about their function, ontogeny, and phylogeny. Therefore, the goal of the study is to investigate trichome morphology and seed coat anatomy in Calycanthaceae to provide more detail characterization. Seeds were collected after that preserved with FAA. Furthermore, alcohol series applied for SEM and light microscopy. The unicellular trichome morphology is common in all species in Calycanthaceae. Density of trichome is highest in Calycanthus occidentalis. Different variation of seed coat and pericarp layers are characteristics of potential phylogenetic significance in the family.
\end{abstract}

\section{Introduction}

Calycanthaceae is small family compromised four genera and ten species. ${ }^{1-6}$ Calycanthaceae is temperate shrubs or tropical trees have relatively large flowers, which are pollinated by beetles. ${ }^{7-10}$ The fossil record of reproductive structures of Calycanthaceae is relatively abundant in earlier. ${ }^{11-15}$ Some of these fossils are extremely well preserved. ${ }^{15}$ Van Heel $^{16}$ studied carpel development. Within Calycanthaceae, gynoecium character is unique to Idiospermum. ${ }^{10}$ Early studies recognized the affinity of Calycanthaceae to Monimiaceae and Lauraceae. ${ }^{16}$ This affinity was acknowledging in the major classification systems of the past 50 years. ${ }^{17-24}$ Molecular phylogenetic analyses settled the family as sister to the rest of Laurales. ${ }^{2-}$ $4,25,26$ These analyses also divided the remaining Laurales into two clades of three families each: the SiparunaceaeAtherospermataceae-Gomortegaceae clade $^{3}$ and the Monimiaceae- HernandiaceaeLauraceae clade. ${ }^{3}$ Within Calycanthaceae, Idiospermum is sister to the rest of the fam- ily and Chimonanthus is sister to the Calycanthus-Sinocalycanthus. ${ }^{1,25}$ In angiosperms, floral phyllotaxis is often variability of various taxonomic feature. ${ }^{27}$ Gynoecium is unique to Idiospermum presence of only one carpel, rarely up to five. ${ }^{1}$. Floral phyllotaxis and architecture were described which is further supported, development of gynocium. ${ }^{28,29}$

Structure and evolution of embryology in Laurales is described. ${ }^{30}$ Seed coat anatomy and trichome morphology of Calycanthacae have not studied. We focus on the seed morphology, seed anatomy, and trichome morphology on Calycanthaceae, which support for the phylogenetic implication. The main objective of this study is to deduce their phylogenetic relationship.

\section{Materials and Methods}

The collected seeds were fixed with the FAA (formalin: glacial acetic acid; 50\% ethanol, 5:5:90, by volume) from each species (Table 1). Mature seeds passed through the alcohol series. After complete dehydration, the seeds passed through combination alcohol/Technovit and then embedded in Technovit 7100 resin.

Serial sections of 5-6 $\mu \mathrm{m}$ thickness were cut using the disposable blade knives stuck into glass slides, and dried on electrical hot plate for 24 hours. Dried slides were, stained with $0.1 \%$ Toluidine blue for $60-90$ second, ringed with running water, and again dried on the electric hotplate for more than 6 hour to remove water. The stained slides then mounted with Entellan (Merck Co., Germany). Four permanent slides observed under the Olympus BX-50 light microscope (Olympus Co., Japan).

The pre-treatment applied for SEM. The preserved seeds were passed through the alcohol series then immersed in 100\% ethanol after that used critical point dryer (CPD) then sample were attached from copper tape. SEM image was carried out from KBSI, Chuncheon at $(\mathrm{EHT}=3.00 \mathrm{KV})$. The multiple image alignments did by using Photoshop CS6.

\section{Results}

Out of one Idiospermum genera we include three genera for this study; Sinocalycanthus Calycanthus and Chimonanthus. Of the 3 genera and eight species included, the seed of Chimonanthus fragrans $(19.2-20 \times 6.1-7.25 \mathrm{~mm})$ is largest and we found that the size and shape were highly variable with in the study of genus small in Calycanthus occidentalis (10.1-
Correspondence: Kweon Heo, Department of Applied Plant Sciences, Kangwon National University, Chuncheon 24341, South Korea. Tel.: +82.33.2506412.

E-mail: laurus@kangwon.ac.kr

Key words: Calycanthaceae; pericarp; seed coat; SEM; trichome.

Funding: none.

Contributions: the authors contributed equally.

Conflict of interest: the authors declare no potential conflict of interest.

Received for publication: 7 December 2017. Accepted for publication: 27 June 2018.

This work is licensed under a Creative Commons Attribution-NonCommercial 4.0 International License (CC BY-NC 4.0).

CCopyright N. Paudel and K. Heo, 2018

Licensee PAGEPress srl, Italy

International Journal of Plant Biology 2018; 9:7525 doi:10.4081/pb.2018.7525

$11.45 \times 5.2-6.65)$. The variable seed feature of the species in order to measurement of seed size (length-width, length/width ratio) these are the significant dissimilarities of the species we concluded That the number of species in genus Chimonanthus is quite large than that of Calycanthus, but in case of Sinocalycanthus is medium size The morphological character is little value for generic delamination in Calycanthaceae. There is difference on seed coat layer, pericarp layer cell shape structure. The seed surface, the seed coat and pericarp character certainly have significant in phylogeny. Detail individual description of the nature of the seed surface and seed coat is given (Tables 2-3). In this studies, seed shape was quite variable large, the range of the helium is concave, long or medium, the range 14.4$16.4 \times 6.4-7.5 \mathrm{~mm}$ the shape of the testal cells either, polygonal or sub polygonal, irregular (Figures 1-3). The wall ornamentation is roughly, most of the cell have construction on the center in (Figure 2A, 2B, $2 \mathrm{C})$ the color of seed was brown in Calycanthaceae (Figure 1), the seed were enclosed in the fleshy hypanthium.

Pericarp separated in three histological zones: exocarp, mesocarp, and endocarp developing from the outer epidermis, mesophyll and inner epidermis. The exocarp is represented by the single layer and tangentially attached with mesocarp (Figures 4C, $4 \mathrm{~L}$ ), thick (Figure 4F). The parenchyma of 
mesocarp regular shape in $C h$. nitens, Ch. fragrans, Ch. salicifolius, Ch. yunnanensis, and $\mathrm{Ch}$. luteus but irregular shape in $\mathrm{Ch}$. praecox, Sinocalycanthus chinensis and $\mathrm{Ca}$. occidentalis. The intercellular spaces developed in the region of mesocarp (Figures 4C, 4F, 4I, 4L, 5C, 5F, 5I, 5L, 6L). The vascular bundle developed in mesocarp (Figures 6A$6 \mathrm{H}, 6 \mathrm{~K})$. Mesocarp layers were thickest in Chimonanthus than that of Calycanthus and
Sinocalycanthus. Endocarp was highly lignified and well developed in Calycanthaceae.

Seed coat divided into three layers as exotesta, mesotesta, and endotesta. Mesotesta was irregular and thick, endotesta and exotesta were polygonal or sub polygonal in Ch. salicifolius (Figure 5E). Exotestal layer was single, circular or subcircular, which is connected the mesotestal layer in Sinocalycanthus chinensis (Figure 4B). The cell shape was circular or sub-circular (Figure 5E). The cell shape was irregular, more than two layers of exotesta in $C h$. fragrans (Figure 5B). Cell shape is circular which is attached with mesotesta in $C h$. luteus. In Ch. salicifolius, the cell was arranged with each other formation of single layered with elongation cell shape (Figure 5E). Single layer was defined in $C h$.

Table 1. Collection information of genus and species used in present study.

Taxa Collection information

Calycanthus occidentalis HooK. \& Arn.

Chimonanthus fragrans (Loisel.) Lind.

Chimonanthus luteus (G.Don) Biel.

Chimonanthus nitens (Oliv.) Rehder

Chimonanthus praecox (L.) Link

Chimonanthus salicifolius S.Y.Hu

Chimonanthus yunnanensis (W.W.Sm.) Hu

Sinocalycanthus chinensis W.C.Cheng \& S.Y.Chang
Korea. Cultivated at Kangwon University, K. Heo \& N. Paudel s.n. 2016 (KWNU)

Korea. Cultivated in Chollipo Arboritum, K. Heo s.n. 2009

Korea. Cultivated in Chollipo Arboritum, K. Heo s.n. 2009 (KWNU)

Korea. Cultivated in Chollipo Arboritum, K. Heo s.n. 2009

Korea. Cultivated at Kangwon University, K. Heo \& N. Paudel s.n. 2016 (KWNU)

Korea. Cultivated in Chollipo Arboritum, K. Heo s.n. 2009

Korea. Cultivated in Chollipo Arboritum, K. Heo s.n. 2009

Korea. Cultivated at Kangwon University, K. Heo \& N. Paudel s.n. 2016 (KWNU)

Table 2. Seed morphology and measurement.

\begin{tabular}{|c|c|c|c|c|c|c|c|}
\hline Taxa & Seed shape and size & Seed character & Cell shape & $\begin{array}{r}\mathrm{N} \\
0 \\
\text { Pericarp }\end{array}$ & $\begin{array}{l}\text { Vumber } \\
\text { of layer } \\
\text { p Seed coat }\end{array}$ & $\begin{array}{l}\text { Seed coat } \\
\text { width in } 11 \mathrm{~m}\end{array}$ & Tegmen \\
\hline $\begin{array}{l}\text { Calycanthus occidentalis } \\
\text { Hook. \& Arn. }\end{array}$ & $\begin{array}{l}\text { Elliptical: } \\
10.1-11.45 \times 5.2-6.65\end{array}$ & $\begin{array}{l}\text { Relatively large, } \\
\text { concave, Hairy }\end{array}$ & $\begin{array}{l}\text { Relatively large, } \\
\text { concave }\end{array}$ & $4-5$ & $3-4$ & $124-128$ & 2 layered \\
\hline $\begin{array}{l}\text { Chimonanthus fragrans } \\
\text { (Loisel.)Lind. }\end{array}$ & $\begin{array}{l}\text { Elliptical: } \\
19.2-20 \times 6.1-7.25\end{array}$ & $\begin{array}{l}\text { Relatively large, } \\
\text { concave }\end{array}$ & $\begin{array}{l}\text { Relatively large, } \\
\text { concave, Hairy }\end{array}$ & $4-5$ & $4-5$ & $111-114$ & 2 layered \\
\hline $\begin{array}{l}\text { Chimonanthus luteus } \\
\text { (G.Don) Biel. }\end{array}$ & $\begin{array}{l}\text { Elliptical: } \\
14.4-16.4 \times 6.4-7.5\end{array}$ & $\begin{array}{l}\text { Relatively large, } \\
\text { concave, Hairy }\end{array}$ & $\begin{array}{l}\text { Narrow, subpolygonal } \\
\text { to irregular }\end{array}$ & $4-5$ & $4-5$ & $120-124$ & 2 layered \\
\hline $\begin{array}{l}\text { Chimonanthus nitens } \\
\text { (Olive.) Rehder }\end{array}$ & $\begin{array}{l}\text { Elliptical: } \\
10-11.35 \times 5-6.1\end{array}$ & $\begin{array}{l}\text { Relatively large, } \\
\text { concave, Hairy }\end{array}$ & $\begin{array}{l}\text { Relatively large, } \\
\text { concave }\end{array}$ & $5-6$ & $3-4$ & $110-115$ & 2 layered \\
\hline $\begin{array}{l}\text { Chimonanthus praecox } \\
\text { (L.) Link }\end{array}$ & $\begin{array}{l}\text { Elliptical: } \\
11.1-14 \times 5-6.2-7.1\end{array}$ & $\begin{array}{l}\text { Relatively large, } \\
\text { concave, Hairy }\end{array}$ & $\begin{array}{l}\text { Relatively large, } \\
\text { concave }\end{array}$ & $2-3$ & 3 & $124-129$ & 2 layered \\
\hline $\begin{array}{l}\text { Chimonanthus } \\
\text { salicifolius S.Y.Hu }\end{array}$ & $\begin{array}{l}\text { Elliptical: } \\
11.55-13.75 \times 6.15-7.6\end{array}$ & $\begin{array}{l}\text { Relatively large, } \\
\text { concave, Hairy }\end{array}$ & $\begin{array}{l}\text { Narrow, sub polygonal } \\
\text { to irregular }\end{array}$ & $6-7$ & 3 & $124-128$ & 2 layered \\
\hline $\begin{array}{l}\text { Chimonanthus } \\
\text { yunnanensis (W.W.Sm.)Hu }\end{array}$ & $\begin{array}{l}\text { Elliptical: } \\
12.5-16.35 \times 5.2-7.35\end{array}$ & $\begin{array}{l}\text { Relatively large, } \\
\text { concave, Hairy }\end{array}$ & $\begin{array}{l}\text { Narrow, polygonal } \\
\text { to circular }\end{array}$ & $3-4$ & 3 & $125-128$ & 2 layered \\
\hline $\begin{array}{l}\text { Sinocalycanthus } \\
\text { chinensis W.C.Cheng } \\
\text { \& S.Y. Chang }\end{array}$ & $\begin{array}{l}\text { Elliptical: } \\
12.3-14.35 \times 7-7.65\end{array}$ & $\begin{array}{l}\text { Relatively large, } \\
\text { concave, Hairy }\end{array}$ & $\begin{array}{l}\text { Narrow, elongated } \\
\text { to irregular }\end{array}$ & $4-5$ & $3-4$ & $118-122$ & 2 layered \\
\hline
\end{tabular}

Table 3. Trichome morphology and seed surface in Calycanthaceae.

\begin{tabular}{|c|c|c|c|}
\hline Taxa & $\begin{array}{l}\text { Trichome } \\
\text { Density }\end{array}$ & Surface and direction & Seed surface \\
\hline Calycanthus occidentalis Hook. \& Arn. & Dense & Smooth, Erect & Rough, irregular \\
\hline Chimonanthus fragrans (Loisel.) Lind. & Dense & Smooth, Upward bending (30-45) degree to surface & Slightly pentagonal \\
\hline Chimonanthus luteus (G.Don) Biel. & Dense & Smooth, Upward & Rough, Irregular \\
\hline Chimonanthus nitens (Oliv.) Rehder & Dense & Smooth, Upward bending (45-60) degree to surface & Rough, Irregular \\
\hline Chimonanthus praecox (L.) Link & Dense & Smooth, Erect & Pentagonal \\
\hline Chimonanthus salcifolius S.Y.Hu & Dense & Smooth, Upward & Smooth, pentagonal Shape \\
\hline Chimonanthus yunnanensis (W.W.Sm.) Hu & Dense & Smooth & Rough, Irregular \\
\hline Sinocalycanthus chinensis W.C.Cheng \& S.Y.Chang & Moderate & Smooth, Upward and parallel to surface & Rough, Irregular \\
\hline
\end{tabular}


nitens (Figure 4K).

Endotesta layer was 1, 2 or more connected with each other that formed the interspace gap (Figure 4B, 4E, 4H, 5K). Crystal was observed all Species on Calycanthacae. Tegmen was two layers that formed bitegment

Trichome and seed surface of Calycanthaceae has summarized (Table 3). Non-glandular and unicellular trichomes were representative characters in all species of Calycanthaceae. The density of trichome was dense in $\mathrm{Ca}$. occidentalis and Chimonanthus species but moderate in Sinocalycanthus chinensis. The trichome was erect and bending to the seed surface.
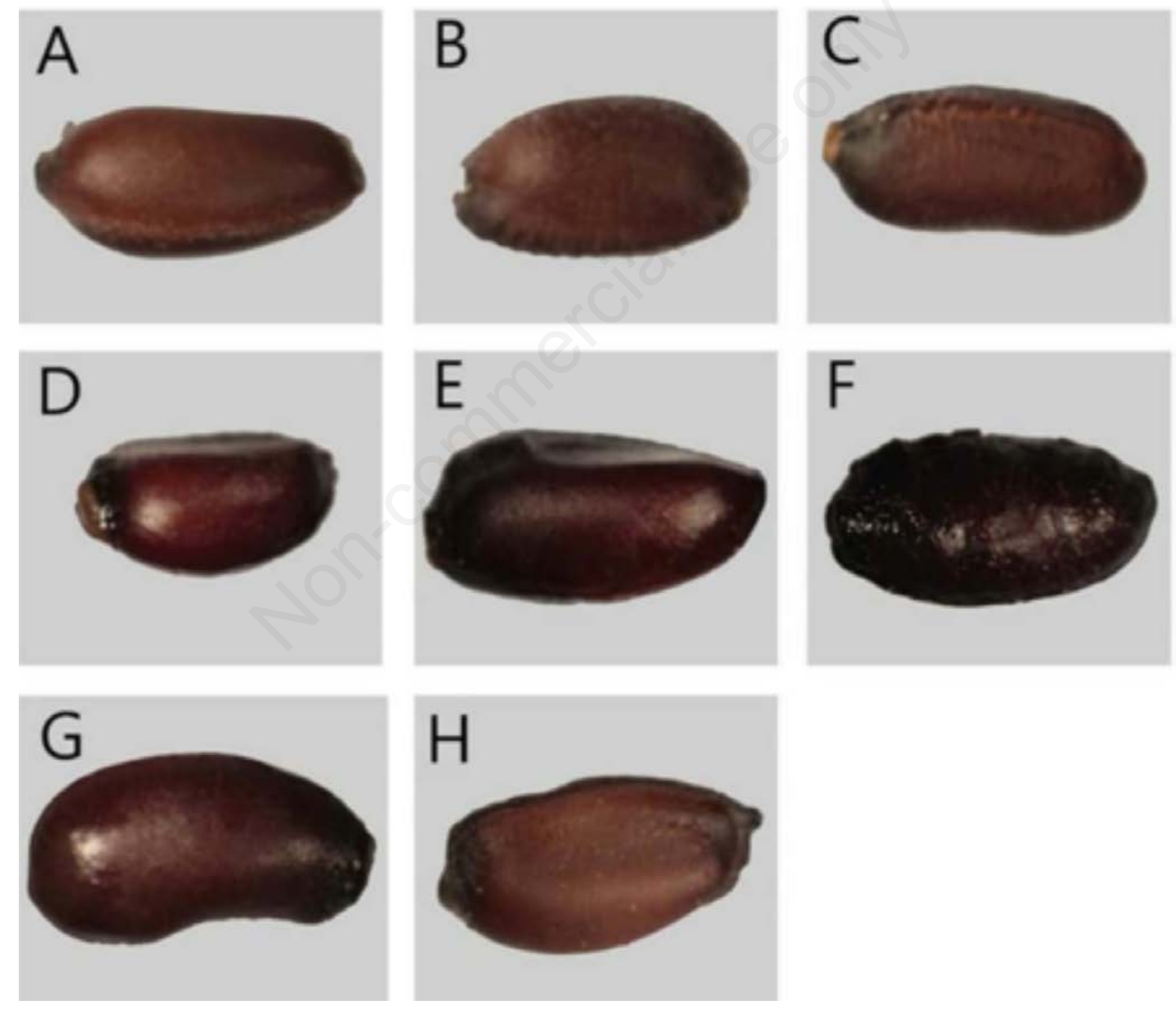

systematic relationship among the species Our result is also similar to the previous finding. ${ }^{31,32}$ The primary vascular cylinder of Calycanthaceae is notable for peculiar system of four-inverted cortical bundle. The stomata are rubiaceous. The trichome is unicellular. We noted that the unicellular hair on the surface of leaf which is the distinguish character of Calycanthaceae.

Unicellular trichomes were variable in length. ${ }^{6}$ Our results were also support density and size of the trichomes, which was important for taxonomy for Calycanthaceae. The surface of seed and angle of direction of trichomes were also supported for the phylogeny (Table 3). Non-
Ch. praecox, Ch. nitens, and Ch. salicifolius Sinocalycanthus and Calycanthus occidentalis, seed surface was rough and irregular.

\section{ture of seed coat and seed surface of ent genus. In addition, it is possible to the \\ This study represents the most compres- sive investigation of trichome micromor- phology, seed surface, and seed anatomy in Calycanthaceae. Our data confirm the struc- \\ Discussion

Figure 1. Seed morphology OF Calycanthaceae from stereo microscope. A, Sinocalycanthus chinensis; B, Calycanthus occidentalis; C, Chimonanthus praecox; D, Chimonanthus nitens; E, Chimonanthus fragrans; F, Chimonanthus salicifolius; G, Chimonanthus yunnanensis; H, Chimonanthus luteus (Without scale; $A-H$ ). 

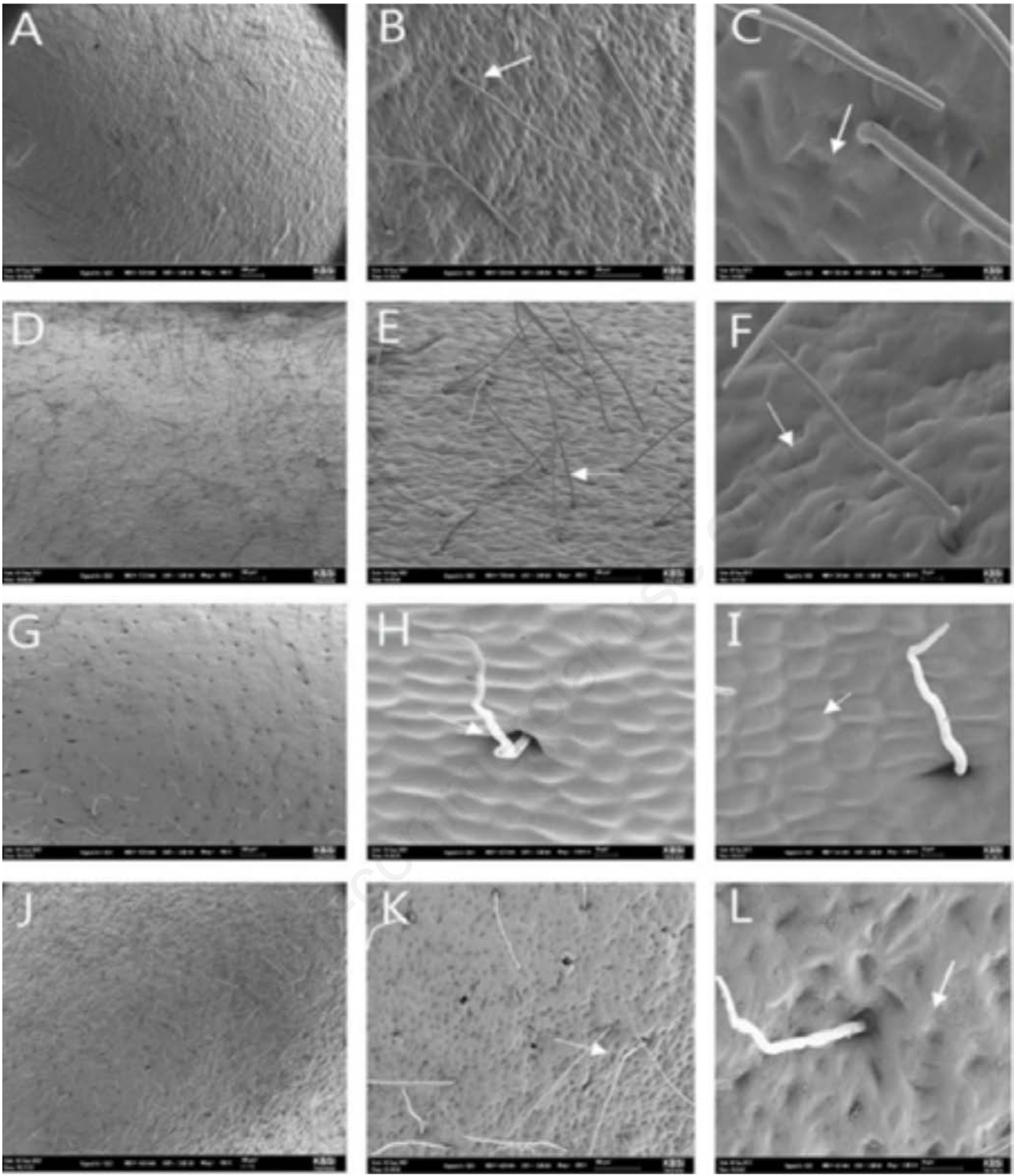

Figure 2. Seed morphology of Calycanthaceae from SEM. A-C, Sinocalycanthus chinensis; D-F, Calycanthus occidentalis; G-I, Chimonanthus praecox; J-L, Chimonanthus nitens. (Trichome, E, H, K; Seed surface C, F, I, L). 

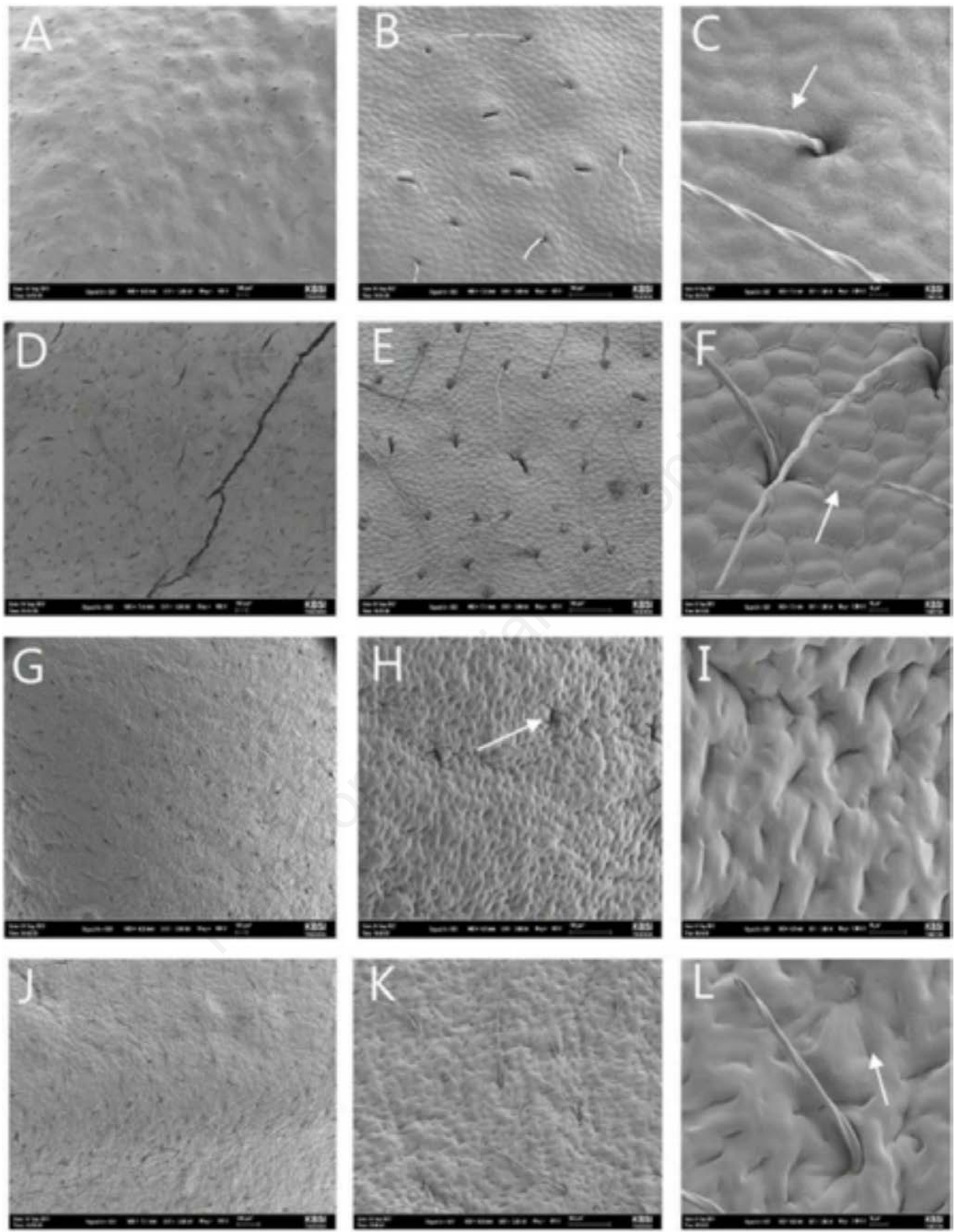

Figure 3. Seed morphology of Calycanthaceae from SEM. A-C, Chimonanthus fragrans; D-F, Chimonanthus saliicifolius; G-I, Chimonanthus yunnanensis; J-L Chimonanthus luteus. (Trichome, E, H, K; Seed surface C, F, I, L). 

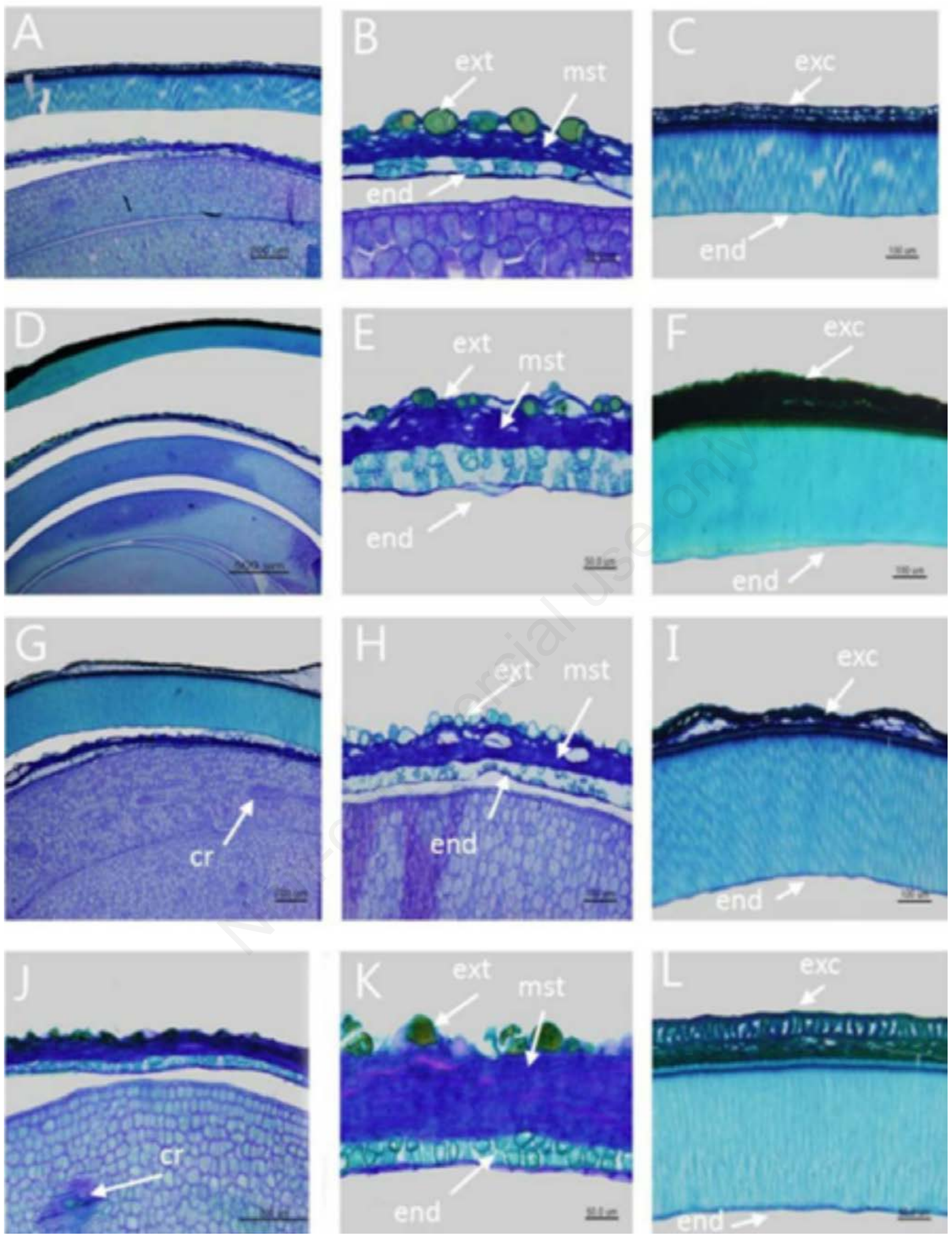

Figure 4. Seed anatomy of Calycanthaceae. A-C, Sinocalycanthus chinensis; D-F, Calycanthus occidentalis; G-I, Chimonanthus praecox; J-L, Chimonanthus nitens. Abbreviation: end, endotesta; ext, exotesta; mst, mesotesta; exc; exocarp; enc, endocarp; cr, crystal. 

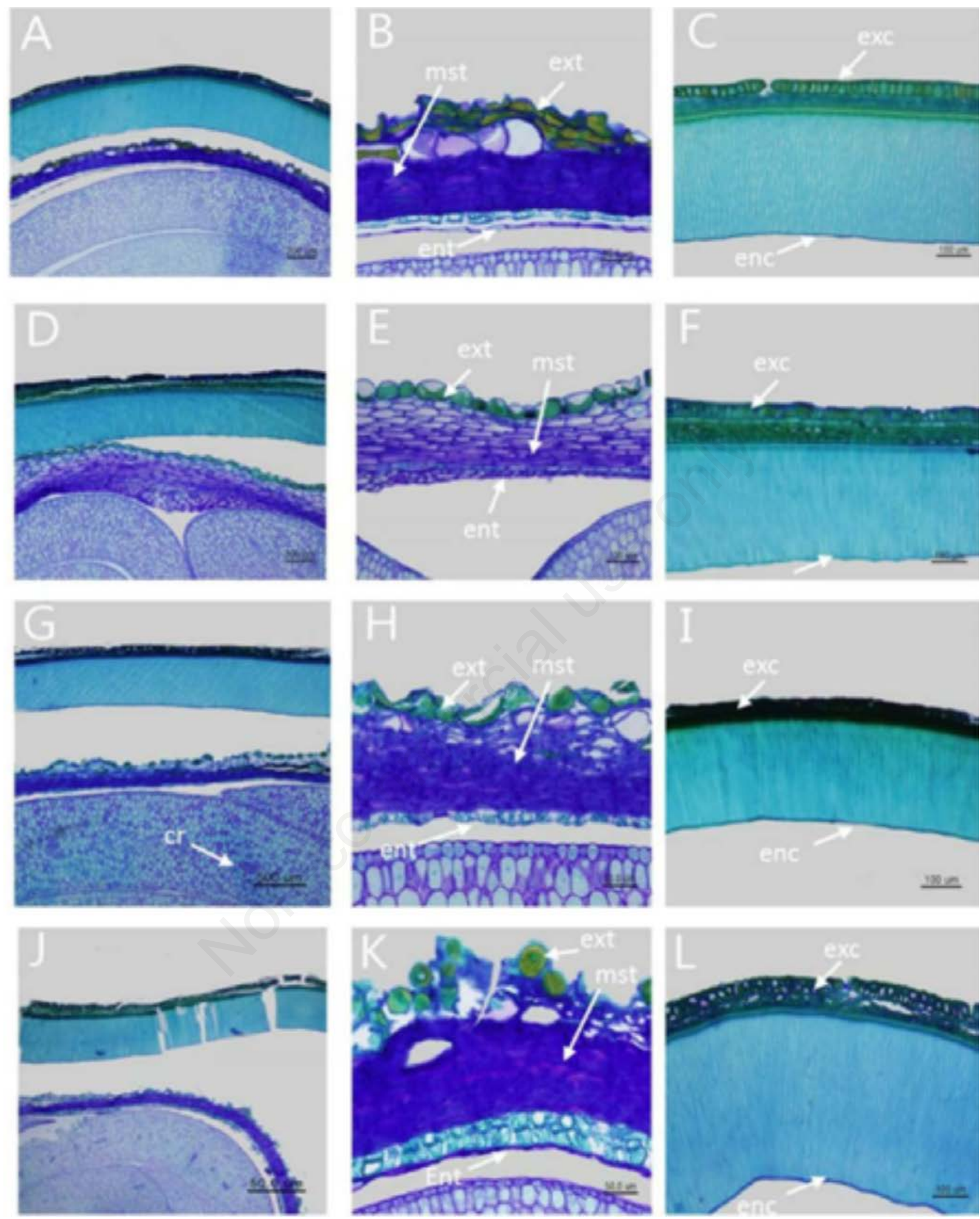

Figure 5. Seed anatomy of Calycanthaceae. A-C, Chimonanthus fragrans; D-F, Chimonanthus salicifolius; G-I, Chimonanthus yunnanensis; J-L, Chimonanthus luteus. Abbreviation: ent, endotesta; ext, exotesta; mst, mesotesta; exc, exocarp; enc, endocarp; cr, crystal . 

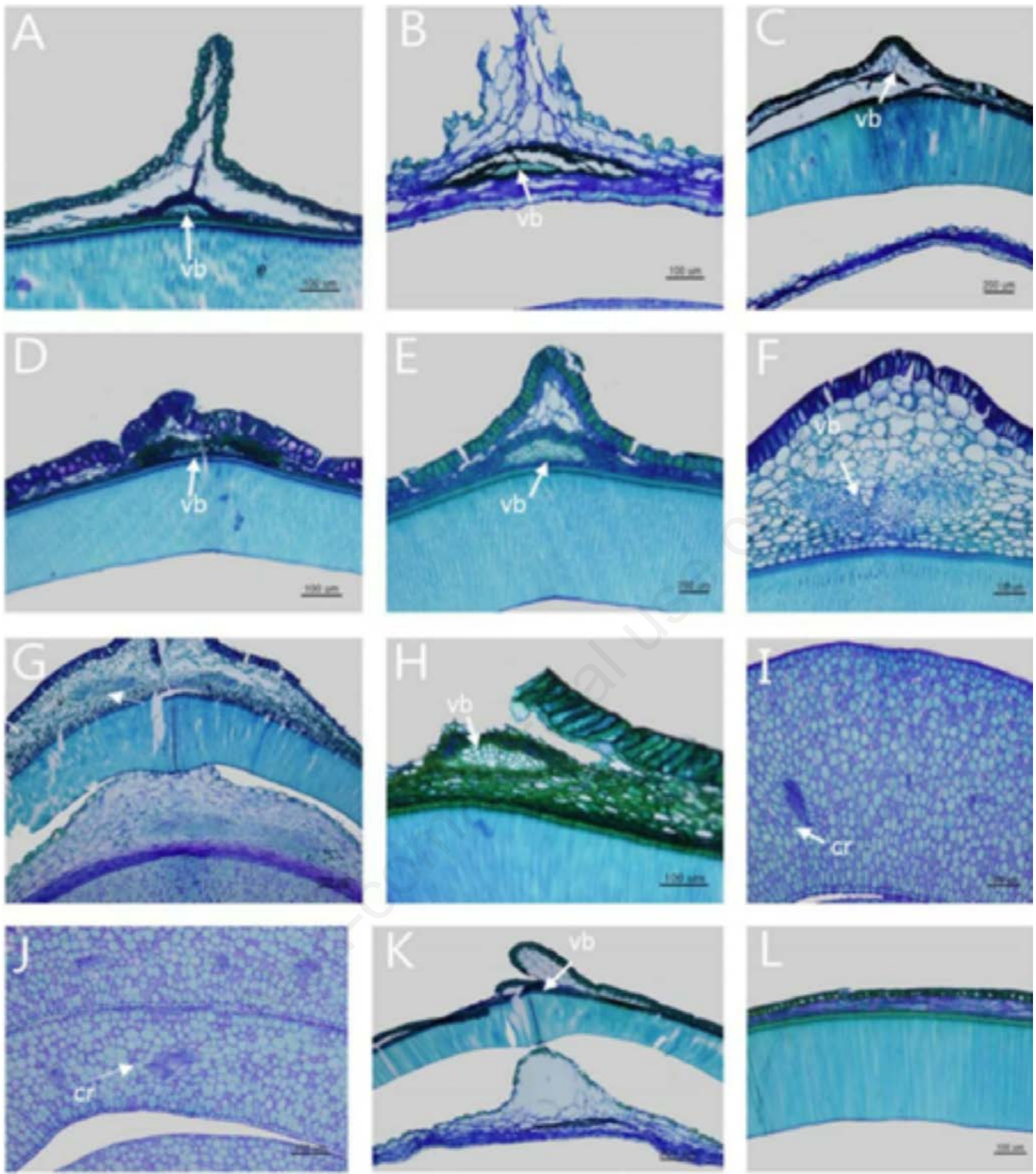

Figure 6. Seed anatomy of Calycanthaceae. A, Sinocalycanthus chinensis; B and K, Calycanthus occidentalis; C, Chimonanthus praecox; D and L, Chimonanthus nitens; E, Chimonanthus fragrans; F and G, Chimonanthus salicifolius; H and I, Chimonanthus luteus; J, Chimonanthus yunnanensis. Abbreviation: $\mathrm{Vb}$, vascular bundle; cr, crystal. 
glandular trichome is a little diagnostic feature of the Calycanthaceae. ${ }^{33}$ Unicellular trichome is common in all species. The density and position of the trichome play importance role on systematic in Calycanthaceae. We found smooth and erect trichome in all species. They are varying in their arrangement to the seed surface. Variation of seed surface structure is another strong character for the Calycanthaceae. Pentagonal shape recorded in Chimonanthus praecox, Chimonanthus fragrans, and Chimonanthus salicifolius (Figures 2L, 2C, 2F). Sinocalycanthus chinensis and Calycanthus occidentalis represented as rough and irregular shape (Figures 2C, 2F). Chimonanthus nitens, Chimonanthus yunnanensis, and Chimonanthus luteus are irregular and rough (Figures 2L, 3I, 3L).

The seed of Chimonanthus fragrans is largest. Seeds feature of the species in order to measurement of the seed size was the significant dissimilarities of the species. We concluded genus Chimonanthus is quite larger than that of Calycanthus, but Sinocalycanthus is medium size. The morphological characters are for generic delamination in Calycanthaceae. There is difference seed characters have significant for phylogeny. The great consultancy of seed coat feature has observed in Calycanthaceae. The all species of Calycanthus have specialized mesocarp feature. In the seed coat anatomy, all species have thicker mesotestal layer. The vascular bundle is in cortex, which is independent to the stellar system through the Calycanthaceae. ${ }^{34}$

The exotesta was arranged ovate shape in Chimonanthus praecox, Ch. salicifolius, and Ch. luteus. In case of Chimonanthus fragrans, Ch. nitens, and Ch. yunnanensis, the seed shapes were elliptical shape. Calycanthus occidentalis and Sinocalycanthus show the circular exotesta. Exotesta is highly developed in the Chimonanthus than Sinocalycanthus and Calycanthus.

\section{Conclusions}

Seed coat anatomy is different in Calycanthaceae. From the results, seed coat developed in the Chimonanthus than Sinocalycanthus, and Calycanthus endotesta shows broad.

The mesotesta is thicker than exotesta and endotesta in Sinocalycanthus and Calycanthus .In Calycanthus pericarp contain hard comprise the stony cells. The pericarp divided as the exocarp, mesocarp, and endocarp. The exocarp is single layer cells and thin than that of other.

Our data show that trichome micromorphology and seed surface are useful for the separation of species within characterizing of genus and species. There are only on reliable of molecular phylogenetic known as the sister group of Laurales. ${ }^{6}$ One important result of the above-mentioned surface was rough in both Sinocalycanthus and Calycanthus. Non-glandular trichome was dense in Calycanthus occidentalis. In this study, seed morphology and seed coat anatomy provide some useful information in the genetic delimitation of Calycanthaceae. Number of pericarp layer, number of seed coat layer, and shape of cell were distinguished features. Nature of the tegmen, seed shape and seed size are for species delineation. Presence of crystal in all species has no value for the species delimited. Trichome density and seed surface were great value for the genus level.

\section{References}

1. Zhou S, Renner SS, Wen J. Molecular phylogeny and intra-and intercontinental biogeography of Calycanthaceae. Mol Phylogenet Evol 2006;39:1-15.

2. Renner SS. Circumscription and phylogeny of the Laurales: evidence from molecular and morphological data. Am J Botany 1999;86:1301-15.

3. Renner SS. Variation in diversity among Laurales, Early Cretaceous to present. Biologiske Skrifter/Kongelike Danske Videnskabernes Selskab 2005;55:441-58.

4. Qiu YL, Dombrovska O, Lee J, et al. Renner SS. Phylogenetic analyses of basal angiosperm based on nine plastid, mitrochondrial, and nuclear genes. Int $\mathbf{J}$ Plant Sci 2005;166:815-42.

5. Cheng WC, Chang SY. Genus novum Calycanthacearum chinae orientalis. Acta Phytotax 1964;9:137-8.

6. Nicely KA. A monographic study of the Calycanthaceae. Castanea 1965; 38-81.

7. Grant B. The pollination of Calycanthus occidentalis. Am J Bot 1950;37:294-7.

8. Badrutt S. Struktur und Funktion der Blüten bei Calycanthaceae. Diploma thesis. University of Zurich; 1992.

9. Vogel S. Remarkable nectaries: structure, ecology, organophyletic perspectives. II. Nectarioles. Flora 1998;193:129.

10. Worboys SJ, Jackes BR. Pollination processes in Idiospermum australiense (Calycanthaceae), an arborescent basal angiosperm of Australia's tropical rain forests. Plant Syst Evol 2005;25:10717.
11. Mai HM. Neue Arten nach Fru chten und Samen aus dem Tertiar von Nordwestsachsen und der Lausitz. Feddes Report 1987;98:105-26.

12. Friis EM, Eklund H, Pedersen KR, Crane PR.Virginianthus calycanthoides genet sp. nov. - a calycanthaceous flower from the Potomac Group (Early Cretaceous) of eastern North America. Int J Plant Sci 1994;155:772-85.

13. Herendeen PS, Magallon-Puebla S, Lupia R, et al . A preliminary conspectus of the Allon flora from the Late Cretaceous (Late Santonian) of central Georgia, USA. Ann Mo Bot Gard 1999;86:407-71.

14. Mohr BA, Eklund H. Araripia florifera, a magnoliid angiosperm from the Lower Cretaceous Crato Formation (Brazil). Rev Palaeobot Palynol 2003;126:279-92.

15. Crepet WL, Nixon KC, Gandolfo MA. An extinct calycanthoid taxon, Jerseyanthus calycanthoides, from the Late Cretaceous of New Jersey. Am J Botany 2005;92:1475-85.

16. Van Heel, WA .Variation in the development of ascidiform carpels. Blumea 1984;29:443-52.

17. Cronquist, A. Outline of a new system of families and orders of the dicotyledons. Bull Jard Bot Brux 1957; 27:1340.

18. Cronquist A. An Integrated System of Classification of Flowering Plants. Columbia University Press, New York 1981.

19. Cronquist A. The Evolution and Classification of Flowering Plants $2^{\text {nd }}$ Ed. New York Botanical Garden, New York 1988.

20. Takhtajan AL. Outline of the classification of flowering plants (Magnoliophyta). The Bot Rev 1980; 46:225-359.

21. Thorne RF. A phylogenetic classification of the Annoniflorae. Aliso: A Journal of Systematic and Evolutionary Botany 1974; 8:147-209.

22. Thorne RF. Classification and geography of the flowering plants. The Bot Rev 1992;58:225-327.

23. Throne RF. The classification and geography of the flowering plants: Dicotyledons of the class Angiospermae (subclasses Magnoliidae, Ranunculidae, Caryophyllidae, Dilleniidae, Rosidae, Asteridae, and Lamiidae). Bot Rev 2000; 66:441-647.

24. Dahlgren R, Bremer K. Major clades of the angiosperms. Cladistics 1985;1:349-368.

25. Soltis DE, Solits PS, Chase MW, Mort ME, Albach DC, Zanis Savolainen V, 
Hahn WH, Hoot T, SB., Fay MF, Axteel M. Angiosperm phylogeny inferred from $18 \mathrm{~S}$ rDNA, rbcL, and atpB sequences. Botan J Linn Soc 2000; 133:381-461.

26. Li Y, Li PT. Cladistic analysis of Calycanthaceae. J Trop Subtrop Bot (China) 2000;8:275-281.

27. Endress PK. Dispersal and distribution in some small archaic relic angiosperm families (Austrobaileyaceae, Eupomatiaceae, Himantandraceae, Idiospermoideae-Calycanthaceae). Sonderbd naturwiss Ver Hamburg 1983;7:201-217.
28. Staedler YM, Weston PH, Endress, PK. Floral phyllotaxis and floral architecture in Calycanthaceae (Laurales). Int J Plant Sci 2007;168: 285-306.

29. Staedler YM, Weston PH, Endress PK. Comparative gynoecium structure and development in Calycanthaceae (Laurales). Int J Plant Sci 2009;170:2141.

30. Heo K, Kimoto Y, Riveros M, Tobe H. Embryology of Gomortegaceae (Laurales): characteristics and character evolution. J Plant Res 2004;117:211-8.

31. Fan LK, Lu YM, Yan, GJ,Zhang, QX. Classification of Chinese wintersweet
(Chimonanthus praecox) cultivars supported by pollen morphology. Sci Agric Sin 2010;9:958-64.

32. Wilson CL. Floral anatomy of Idiospermum australiense (Idiospermaceae). Am. J. Bot. 1976; 63:987-96.

33. Carlquist, S. Vessel Grouping in Dicotyledons Wood Aliso 1984;10:50525.

34. Behnke HD. Sieve-element plastids, phloem protein, and evolution of flowering plants: III. [4] Magnoliidae. Taxon. 1988;37:699-732. 